\title{
Pengaruh Saluran Distribusi dan Promosi Terhadap Kinerja Pemasaran (Studi Kasus Pada UKM Furniture Kota Semarang)
}

\author{
Sendhang Nurseto ${ }^{1, *}$ \\ ${ }^{1}$ Departemen Administrasi Bisnis, Fakultas Ilmu Sosial Ilmu Politik, Universitas Diponegoro \\ *Email: sendhang_1981@yahoo.co.id
}

\begin{abstract}
Realization of production every year on average only reaches $90 \%$ of the target. The problems in this research are: a) How does the Infuence of Distribution Channels to Marketing Performance?; b) How does the Infuence of Promotion to Marketing Performance?; c) How does the Infuence of Distribution Channels and Promotion to Marketing Performance simultaneously? Results from this study are, there is an influences of distribution channels for marketing performance, with 5,751 t value and significance $0.000<$ 0.005 . There is an influence of promotion on the performance of the marketing campaign with 8,631 t value and significance $0.000<0.005$. There is the influence of distribution channels and promotion simultaneously on marketing performance with $F$ count 38.788 and significance $0.000<0.005$. However, according to the researchers there are some things that could be improved. Among other things need to improve is the convenience for the customer visiting the store. Promotion is done by entrepreneurs pretty good, But it would be better if employers follow the exhibition events held in major cities on a regular basis.
\end{abstract}

\begin{abstract}
Abstraksi Realisasi produksi setiap tahun rata-rata hanya mencapai $90 \%$ dari target. Permasalahan dalam penelitian ini adalah: a) Bagaimana Pengaruh Saluran Distribusi terhadap Kinerja Pemasaran?; b) Bagaimana Pengaruh Promosi terhadap Kinerja Pemasaran?; c) Bagaimana Pengaruh Saluran Distribusi dan Promosi terhadap Kinerja Pemasaran secara bersamaan?. Hasil dari penelitian ini adalah, terdapat pengaruh saluran distribusi terhadap kinerja pemasaran, dengan nilai t 5,751 dan signifikansi $0,000<0,005$. Ada pengaruh promosi terhadap kinerja kampanye pemasaran dengan nilai t 8,631 dan signifikansi $0,000<0,005$. Ada pengaruh saluran distribusi dan promosi secara simultan terhadap kinerja pemasaran dengan $\mathrm{F}$ hitung 38,788 dan signifikansi $0,000<0,005$. Namun, menurut para peneliti ada beberapa hal yang bisa diperbaiki. Di antara hal lain yang perlu ditingkatkan adalah kenyamanan bagi pelanggan yang mengunjungi toko. Promosi yang dilakukan oleh pengusaha cukup baik, tetapi akan lebih baik jika pengusaha mengikuti acara pameran yang diadakan di kota-kota besar secara rutin.
\end{abstract}

Keywords: Channel Distribution; Marketing Performance; Promotion

\section{Pendahuluan}

Salah satu usaha kecil menengah yang ada di Kota Semarang adalah bidang furnitur dan mebel. Furnitur atau yang sering disebut dengan mebel merupakan produk yang termasuk dalam kebutuhan rumah tangga sehingga furnitur bukan menjadi barang kebutuhan yang langka tetapi memang diperlukan oleh masyarakat. Berdasarkan pendataan kapasitas produksi furnitur yang dihasilkan pengrajin Kota Semarang selama tahun 2011 sampai 2013, diperoleh hasil yang dapat dilihat pada Tabel 1.

Data di atas menunjukkan bahwa setiap tahun realisasi produksi yang diharapkan tidak sesuai dengan target yang diinginkan. Realisasi produksi setiap tahun rata-rata hanya menjangkau 90\% dari target. Produksi yang dihasilkan setiap tahun juga mengalami fluktuasi, hampir setiap tahun mengalami penurunan. Hasil ini tentunya belum seperti yang diharapkan, dimana pengrajin tentunya menginginkan peningkatan produksi setiap tahunnya. Fenomena lain yang menunjukan lemahnya perkembangan UKM Furniture di Kota Semarang. Hal itu juga didukung oleh penelitian terdahulu yaitu diantaranya: (1) Terbatasnya saluran distribusi yang digunakan; (2) Kurangnya kegiatan promosi yang telah dilakukan

Berdasarkan latar belakang yang telah 
Tabel 1. Kapasitas Produksi Furnitur di Kota Semarang Tahun 2011 - 2013

\begin{tabular}{cccc}
\hline Tahun & $\begin{array}{l}\text { Target } \\
\text { (buah) }\end{array}$ & $\begin{array}{l}\text { Realisasi } \\
\text { (buah) }\end{array}$ & $\begin{array}{l}\text { Prosentase } \\
\text { Perubahan(\%) }\end{array}$ \\
\hline 2011 & 750.000 & 697.388 & 93 \\
2012 & 550.000 & 488.172 & 89 \\
2013 & 500.000 & 414.946 & 83 \\
\hline
\end{tabular}

Sumber: Disperindag Kota Semarang, 2014.

diuraikan, ditekankan bahwa UKM merupakan bagian besar penggerak ekonomi suatu wilayah bahkan dalam area yang lebih besar Negara. Pengusaha kecil, khususnya pengusaha industri kreatif dalam hal ini produk furniture memerlukan suatu kreasi atau terobosan-terobosan baru, dikarenakan sektor ini merupakan sektor yang selalu terpengaruh trend pasar. Permasalahan dalam penelitian ini adalah: (1) Bagaimana pengaruh Saluran Distribusi terhadap Kinerja Pemasaran?; (2) Bagaimana pengaruh Promosi terhadap Kinerja Pemasaran?; (3) Bagaimana pengaruh Saluran Distribusi dan Promosi terhadap Kinerja Pemasaran secara bersamaan?

\section{Metode}

\section{Tipe Penelitian}

Jenis penelitian ini adalah eksplanatori yang bermaksud menjelaskan kedudukankedudukan variabel-variabel yang diteliti serta hubungan antara satu variabel dengan variabel yang lain.

\section{Populasi dan Sampel Penelitian}

Populasi dalam penelitian ini adalah 64 pengrajin furniture yang produknya telah diekspor pada UKM furniture Kota Semarang, dengan sampel sebanyak 55 responden. Cara pemilihan sampel (responden) yang digunakan dalam penelitian ini menggunakan teknik non probability sampling dengan teknik sampling purposive yaitu teknik penentuan sampel dengan pertimbangan tertentu.
Responden yang dipilih dalam penelitian ini adalah yang memiliki syarat yaitu: (1) Memiliki kekayaan bersih lebih dari Rp50.000.000,00 sampai dengan paling banyak Rp1.000.000.000,00; (2) Usaha yang didirikan telah berjalan minimal 3 tahun.

\section{Teknik Analisis}

Analisis deskriptif digunakan untuk mendeskripsikan variabel Saluran Distribusi, Promosi dan Kinerja Pemasaran dengan jalan mendistribusikan item-item dari masingmasing variabel. Setelah keseluruhan data terkumpul, maka kegiatan selanjutnya mengolah data kemudian mentabulasikan ke dalam tabel frekuensi dan kemudian membahas data yang diolah tersebut secara deskriptif. Tolak ukur dari pendeskripsian itu adalah dengan pemberian angka, baik dalam jumlah maupun persentase. Regresi linear berganda adalah keadaan naik atau turunnya variabel dependen, bila dua atau lebih variabel independen sebagai faktor prediktor dimanipulasi (dinaik turunkan nilainya).

\section{Hasil \\ Saluran Distribusi UKM Furniture di Kota Semarang}

Saluran distribusi mempunyai peranan yang penting dalam keberlangsungan penyampaian produk dari produsen ke konsumen akhir. Pengertian saluran distribusi adalah merupakan aliran produk dari perusahaan, distributor, sampai ke pasar sehingga konsumen dapat memenuhi kebutuhan dan keinginannya. Saluran distribusi juga disebut sebagai rangkaian aktifitas dari produsen ke konsumen dimana pelaksanaannya dilakukan oleh distributor (Narus \& Anderson, 1988). Berkat saluran distribusi, maka produk dapat sampai ke tangan konsumen (Orpha Jane, 1997).

Persepsi responden mengenai variabel saluran distribusi di UKM furniture Kota Semarang adalah baik. Hal ini bisa dilihat dari pemahaman tentang jumlah dan jangkauan distributor yang cukup baik, selisih rentang waktu pengiriman tiap-tiap tujuan yang baik, keragaman item yang tersedia yang cukup 
baik, dan proses pengiriman yang dilakukan distributor saat melakukan pembelian yang baik. Adapun pernyataan tidak baik, dikarenakan oleh kurang pahamnya responden mengenai pentingnya kenyamanan bagi pembeli.

Berbeda dengan penelitian sebelumnya dimana saluran distribusi saat itu terbatas hanya pada pada kota-kota kecil sekitar Semarang, sehingga menghambat kinerja pemasaran UKM tersebut. Saat ini saluran distribusi UKM sudah mencakupi wilayah yang lebih luas, walaupun masih di dalam Propinsi Jawa Tengah. Antara lain sudah terdistribusi hingga wilayah Wonosobo, Cilacap, Tegal, Solo dan Rembang.

\section{Promosi UKM Furniture di Kota Semarang}

Pengertian Promosi menurut Nickels (1996) adalah arus informasi atau persuasi satu arah yang dibuat untuk mengarahkan seseorang atau organisasi kepada tindakan yang menciptakan pertukaran dalam pemasaran. Bagaimanakah lagkah perusahaan dalam memberikan informasi kepada konsumen inilah sebagai kunci dalam menciptakan pertukaran. Informasi mengenai keunggulan produk, informasi mengenai nilai tukar yang akan diperoleh selama menggunakan produk tersebut.

Persepsi responden mengenai variabel promosi di UKM furniture Kota Semarang adalah cukup baik dan cenderung baik. Hal ini dapat dilihat pada ketepatan media dalam mengiklankan produk yang cukup baik, dan Pembekalan kemampuan dalam memberi informasi produk yang cukup baik.

Adapun pernyataan tidak baik, dikarenakan oleh pengetahuan mengenai trend yang tidak memadai, kurangnya modal dan hanya mendasarkan pada produk yang lama.

Berbeda dengan penelitian sebelumnya, dimana promosi hanya dilakukan melalui Word of Mouth. Saat ini UKM Furniture di Kota Semarang juga telah melakukan promosi melalui pelayanan yang baik, dan juga melalui brosur dan spanduk.
Kinerja Pemasaran UKM Furniture di Kota Semarang

Kinerja pemasaran merupakan elemen penting dari kinerja perusahaan secara umum karena kinerja suatu perusahaan dapat dilihat dari kinerja pemasarannya selama ini. Kinerja pemasaran merupakan konsep untuk mengukur prestasi pemasaran suatu perusahaan. Setiap perusahaan berkepentingan untuk mengetahui prestasinya sebagai cermin dari keberhasilan usahanya dalam persaingan pasar. Slater dan Narver (1995) menggambarkan hasil dari penerapan strategi perusahaan diantaranya berupa kepuasan konsumen, kesuksesan produk baru, peningkatan penjualan, dan profitabilitas perusahaan.

Persepsi responden mengenai variabel Kinerja Pemasaran di UKM Furniture Kota Semarang adalah baik. Hal tersebut dapat dlihat pada tingkat pertumbuhan penjualan produk furniture setahun terakhir yang baik, jumlah pelanggan yang tercatat setahun terakhir yang baik, tingkat perputaran pelanggan yang baik, dan jumlah keuntungan setahun terakhir yang baik.

Adapun pernyataan tidak baik, dikarenakan beberapa responden mengalami kelesuan bisnis. Kelesuan tersebut disebabkan oleh menurunnya kentungan yang diperoleh.

\section{Pembahasan}

Hasil penelitian menunjukkan bahwa Saluran Distribusi dan Promosi mempengaruhi Kinerja Pemasaran secara signifikan pada UKM Furniture Kota Semarang. Saluran Distribusi yang baik akan memperluas cakupan pemasaran, sehingga akan meningkatkan jumlah pelanggan. Dan juga, dengan saluran distribusi yang baik akan memberikan efektifitas dan efisiensi dalam mendistribusikan produk nya. Dimana kedua hal tersebut bermuara pada kinerja pemasaran yang semakin membaik.

Begitu pula dengan promosi yang baik. Akan dapat meningkatkan awareness produk pada benak konsumen yang akan berdampak pada meningkatnya kinerja pemasaran. 


\section{Kesimpulan dan Saran}

Berdasarkan hasil penelitian mengenai saluran distribusi dan promositerhadap kinerja pemasaran UKM Furniture Kota Semarang, dapat disimpulkan sebagai berikut: (1) Persepsi responden mengenai variabel saluran distribusi di UKM furniture Kota Semarang adalah baik; (2) Persepsi responden mengenai variabel promosi di UKM furniture Kota Semarang adalah cukup baik dan cenderung baik ; (3) Persepsi responden mengenai variabel Kinerja Pemasaran di UKM Furniture Kota Semarang adalah baik ; (4) Terdapat pengaruh saluran distribusi terhadap kinerja pemasaran, hal tersebut dapat dilihat dari nilai t hitung 5,751 dengan signifikansi $0,000<$ 0,005 maka dapat diambil kesimpulan bahwa menerima hipotesis penelitian yang berbunyi "diduga terdapat pengaruh antara saluran disrtribusi terhadap kinerja pemasaran." ; (5) Terdapat pengaruh promosi terhadap kinerja pemasaran, hal ini bisa dilihat dari tabel $t$ diketahui bahwa $\mathrm{df}=\mathrm{n}-\mathrm{k}=55-2=53$. Sehingga nilai $\mathrm{t}$ tabel untuk $\mathrm{df}=53$ pda alpha $5 \%$ adalah sebesar 2,006 . Nilai t hitung 8,631 dengan signifikansi $0,000<0,005$ maka dapat diambil kesimpulan bahwa menerima hipotesis penelitian yang berbunyi "diduga terdapat pengaruh antara promosi terhadap kinerja pemasaran"; (6) Berdasarkan tabel $\mathrm{F}$, diketahui bahwa (n-k-1) $=(55-2-1)=52$. Sehingga nilai $\mathrm{F}$ tabel pada alpha $5 \%$ adalah sebesar 3,175 . Nilai $F$ hitung 38,788 dengan signifikansi $0,000<0,005$, dari perhitungan tersebut dapat diambil kesimpulan bahwa Ho ditolak dan Ha diterima yang berarti bahwa "terdapat pengaruh antara saluran distribusi dan promosi terhadap kinerja pemasaran".

\section{Daftar Referensi}

Amabile, Teresa M. (1996). Assesing The Work Environment For Creativity. Academy of Management Journal, p.1154-1184.

Arikunto, Suharsimi. (2006). Prosedur Penelitian Suatu Pendekatan Praktek. Bandung: Rineka Cipta.

Astuti, Sih Darmi dan J. Widiatmoko. (2003).
Profil Usaha Kecil Menengah (UKM) di Jawa Tengah. Jurnal Fokus Ekonomi, Volume 2 Nomor 3, pp. 215-228.

Ayyagari, M., Beck, T., and A. DemirgüçKunt. (2003). Small and Medium Enterprises across the Globe. World Bank Working Paper, WPS2127.

Daellenchbach, S. Ursh., Anne M McCarthy, Timorthy S. Schoenecker. (1999). Commitment to Innovation: The Impact of Top Management Team Characteristic. $R \& D$ Management, 29, 3, pp. 693-716.

Dariska, Eunike. (2007). Analisis Pengaruh Orientasi Pasar Untuk Meningkatkan Keunggulan Bersaing Melalui Inovasi Produk Dan Kinerja Pemasaran (Studi Kasus: UKM di Perkampungan Industri Kecil, Jakarta). Skripsi.

Dewi, Sensi Tribuana. (2006). Analisis Pengaruh Orientasi Pasar Dan Inovasi Produk Terhadap Keunggulan Bersaing Untuk Meningkatkan Kinerja Pemasaran (Studi Pada Industri Batik Di Kota dan Kabupaten Pekalongan). Thesis.

Gaspersz, V. (2001). Analisis Tingkat Produktivitas Industri Manufaktur di Indonesia Periode 1990-1998. Jurnal Ekonomi Pembangunan (JEP), Volume 6 (Nomor 2). pp. 105-121.

Gozhali, Imam. (2001). Aplikasi Analisis Multivariate dengan Program SPSS. Semarang: BP Undip.

Hadjimonalis, Anthanasios., Keith Dickson. (2000). Innovation Strategies of SMEs in Cyprus, A Small Developing Country. International Small Business journal, 18,4 , pp. $62-79$.

Hamel, G., and C. K. Prahalad. (1994). Competing For the Future. Boston: Harvard Business Scholl Press.

Hutabarat, Tito. (2008). Kewirausahaan, Bisnis.com.

http://bisnisekonomi.com/wpcontent/uplo ads/2008/12/kewirausahaan.pdf. diakses 
15 April 2012.

Kotler, Philip. (1997). Manajemen Pemasaran Analisis, Perencanaan,Implementasi dan Kontrol, Jilid 1, terjemahan Hendra Teguh. Jakarta: Prenhallindo.

Rangkuti, Freddy. (2009). Strategi Promosi Yang Kreatif, edisi pertama, cetakan 2.

Sugiyono. (2004). Metode Penelitian Bisnis. Bandung: Alfabeta.

Thong, James Y. L. (1999). An Integrated Model of Information System Adoption in Small Business. Journal of Management Information System, 15, 4, pp. 187-214.
Tjiptono, Fandy. (1995). Strategi Pemasaran. Yogyakarta: Andi.

Umar, Husain. (2002). Strategi Pemasaran. Jakarta: Gramedia Pustaka.

Umar, Husain. (2003). Strategi Pemasaran. Jakarta: Gramedia Pustaka.

Winardi. (2003). Entrepreneur \& Entrepreneurship. Jakarta: Kencana Prenada Media Group.

Zimmerer, W. Thomas Et al. (1996). Entrepreneurship and The New Venture Formation. New Jersey: prentice Hall Inc. 